\title{
Similarities Between European and National Solidarity. An Empirical Thought Experiment About Attitudes Towards Redistribution
}

\author{
Zsófia S. IGNÁCZ \\ Institute of Sociology, Goethe University Frankfurt
}

\begin{abstract}
This paper examines similarities between attitudes towards European redistribution and attitudes towards national redistribution. It maps out possible reasons for expected similarities between the two spatial levels in the degree redistribution is supported and also the underlying mechanisms that foster support rates. To examine the underlying mechanisms, the paper employs a structural equation modelling approach. Despite vastly different institutional settings, findings indicate that the degree of support for redistribution at the national and at the European level are comparable. And we can also identify a similar structure in mechanisms fostering support rates at the European level compared to the one at the national level. Moreover, the strength of these mechanisms is also comparable at the respective spatial level. The results have important consequences for our understanding of transnational mechanisms. They suggest that social entities transcending national borders possess features comparable to national social entities (i.e., nation states). Overall, this potentially suggests that national conflict lines have the capacity to be carried over into the transnational space (e.g., the European social space).
\end{abstract}

Keywords: redistribution, attitudes, European solidarity, cross-national analysis, structural equation modelling, multi-group analysis

\section{Introduction}

The social aspect of European integration has come to the fore in recent years. Beyond vertical Europeanization, which is identified with political and economic integration, horizontal Europeanization has become the focus of scholars (Heidenreich 2019; Mau and Mewes 2012). In particular, the study of European solidarity is gaining prominence. There is a growing body of

${ }^{1}$ Zsófia S. Ignácz is a research associate and lecturer at the Institute of Sociology at Goethe University Frankfurt (ignacz@soz.uni-frankfurt.de). 
literature dealing with the notion of European solidarity and public opinion on European solidarity. Learning about the public opinion on European solidarity is important not only to understand developments in European integration but also for policy makers to gain traction in support for their policy measures reflecting European solidarity.

In empirical social scientific studies that focus on public opinion, European solidarity is an umbrella term connected to many policy fields. In the broadest sense, it means the attitudes and the actions related to extending support to others (both individuals and collective actors) in the European social space with whom one does not share the same national social space, i.e., they are not one's fellow countrymen and countrywomen from a specific region within one's country but live elsewhere within Europe (Raspotnik et al. 2012; cf. Ciornei and Recchi 2017; Lahusen 2020b).

Public opinion towards European solidarity is operationalized in numerous ways. It can be largely divided into three categories: generalized attitudes, policy attitudes, and so-called configuration preferences (see Figure 1). With each category, the degree of abstraction decreases. Generalized attitudes reflect support for the principles of European solidarity, while policy attitudes relate to the support for particular policies. These support rates can be assessed in survey questionnaires. In contrast, configuration preferences reflect the support for policy packages with precise configuration variations. These support rates are typically examined with experimental surveys implementing factorial designs, such as a conjoint analysis.

Figure 1: Conceptual overview of public opinion on European solidarity.

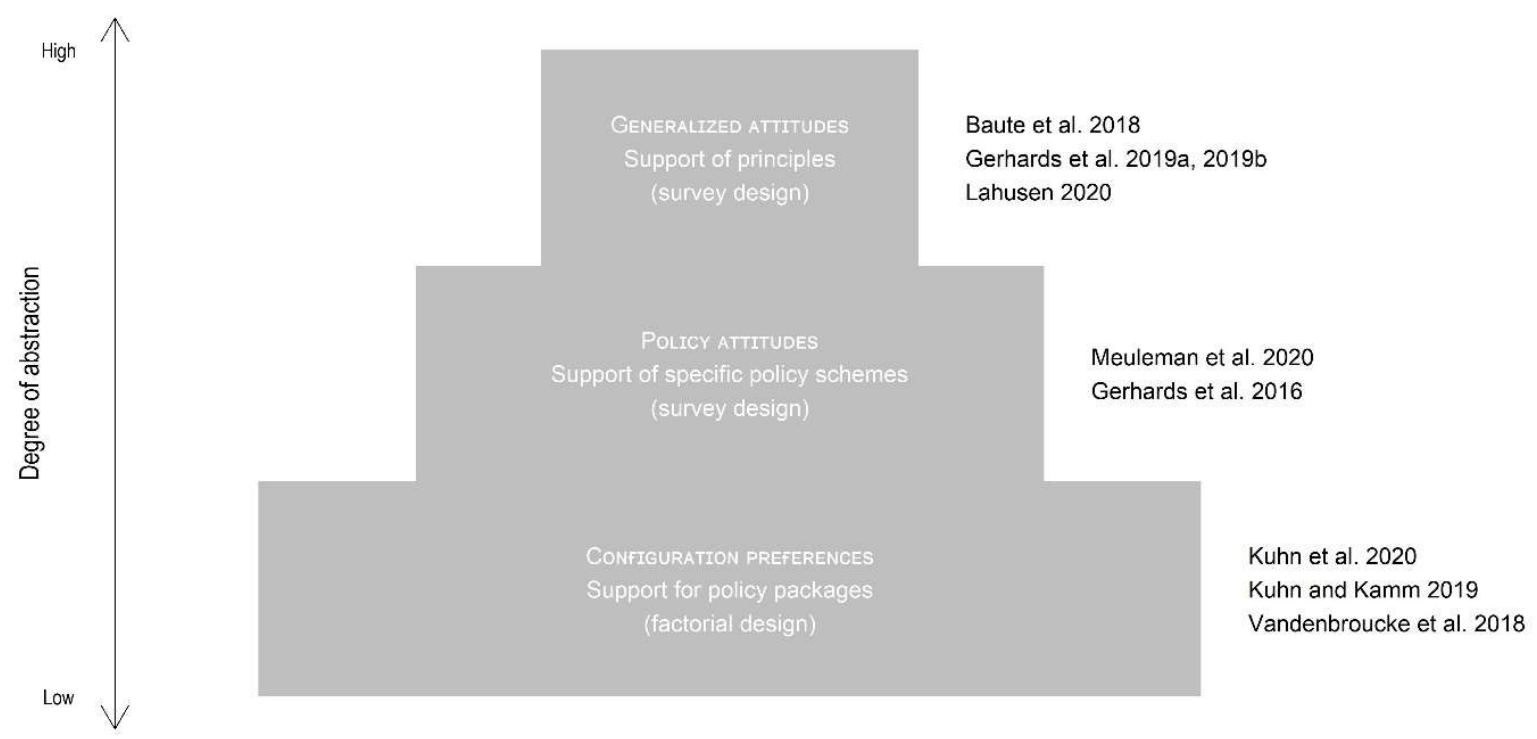

Source: Own depiction.

Given the multi-dimensionality of attitudes towards European solidarity, depending on which topic the surveys focus on and how European solidarity is conceptualized, the assessment of the degree of support and the main drivers for European solidarity varies. This statement applies not only to European welfare solidarity, where the focus is placed on extending support to Eu- 
ropeans in need (Gerhards et al. 2019a), but also to other topical fields. More recently, the general public climate seems more strongly inclined to accept fiscal solidarity (Vasilopoulou and Talving 2020; Verhaegen 2018) compared to the situation directly after the Euro crisis (Bechtel et al. 2014; Kuhn and Stoeckel 2014). Studies relying on conjoint analysis and focusing on configuration preferences paint similar supportive trends both for European welfare state packages (Vandenbroucke et al. 2018; Kuhn and Kamm 2019; Kuhn et al. 2020) and fiscal funds (Bremer et al. 2021). In contrast, the cross-national findings on European civic solidarity are less optimistic; evidence shows that the willingness to extend solidarity is strongly conditional (Lahusen 2020a). The lack of positive support holds true for policy attitudes as well (Meuleman et al. 2020; Baute et al. 2018; Ignácz 2019; Baute and Meuleman 2020). While the degree of support is somewhat contingent on the framing of the topic as demonstrated above, the mechanisms explaining support relay a more uniform message: cultural factors matter more for public opinion on European solidarity than structural factors. Specifically, identification with Europe and one's political left-right position seem to be prominent factors (Kuhn et al. 2020; Verhaegen 2018; Grasso and Lahusen 2020; Gerhards et al. 2019b), although some findings rather identify a person's social standing to be relevant for the support for the extension of solidarity (Gerhards et al. 2019a; Meuleman et al. 2020).

One particular line of argument is missing from these research strands: no study has explicitly contrasted European solidarity with established forms of national solidarity, i.e., solidarity practiced within nation states. Such an enquiry is meaningful as there is a growing discussion about the existence of a European society and whether or not it is a theoretically and empirically plausible notion (Favell and Guiraudon 2011a; Beck and Grande 2007; Fligstein 2010; Kuhn 2015). Thus - if a transnational society is forming in the European social space and solidarity is an important component of society - it is reasonable to assume that the connection between national and European solidarity further underlines the bond between the two spatial levels. Put another way: if we view solidarity, i.e., the readiness to support others, as a necessary ingredient of society, then the investigation of national and European solidarity can reveal a new facet of existing discussions on the similarities and differences between national societies and a European society. More generally, this paper provides food for thought for discussions regarding European society and its features.

The aim of the paper is to assess analogies between European and national solidarity. To this end, the paper utilizes data derived from a cross-national survey, the Transnational European Solidarity Survey (TESS), which provides access to the general public's view on institutionalized solidarity. ${ }^{2}$ For this paper, we use generalized attitudes relating to the principle of redistribution between individuals to tap into public opinions on national and European solidarity. I use generalized attitudes because the institutional backgrounds of national and European solidarity differ strongly. The more the degree of abstraction decreases, the more attitudes reflect the specific institutional background. Thus, the investigation of support for specific policies (policy attitudes) or support for concrete policy measures (configuration preferences) would not serve the theoretical aims of the paper.

\footnotetext{
${ }^{2}$ That means that individuals express their willingness to support a certain institution that distributes goods/resources to recipients. Modern welfare states and their institutions are the most typical forms of institutionalized solidarity. The opposite of institutionalized solidarity is informal solidarity (see van Oorschot et al. 2005).
} 
To investigate European solidarity, the paper focusses narrowly on one topic, namely redistribution between persons. This is justified by the fact that the two main goals of modern national welfare states are: (1) to provide protection against and compensation for social risks, e.g., the risks of being sick, unemployed, or old) (Pettersen 1998), and (2) to reduce social inequality via redistributive policies (Roller 1998). The reduction of inequality by means of redistribution not only directly mitigates income differences between rich and poor people through progressive tax schemes and monetary funding programs but also provides a monetary source to realize a strong social security net. Furthermore, it is associated with one of the prominent values in modern societies: equality (Roosma et al. 2013; Marshall 1964). However, as Jæger (2009) underlines, the topic of redistribution has the potential to strongly divide the general public.

The principle of reduction of inequalities between individuals can easily be carried over to a transnational social setting, that is, the reduction of inequalities among Europeans. Baute and colleagues (2018) have identified that European-level attitudes are akin to national welfare-state attitudes. Thus, this paper operationalizes support for solidarity at the national and at the European level as attitudes towards national and European redistribution, i.e., reduction of inequalities at the national and at the European level.

The analytical framework of this paper is one of its key contributions. Attitudes towards national redistribution are considered a product and/or accessory of nation states, whereas attitudes towards European redistribution are a product and/or accessory of a European society. ${ }^{3}$ Thus, in this paper I will employ an empirical thought experiment where attitudes towards European redistribution are placed next to attitudes towards national redistribution as if Europe were another country among nation states. The framework levels national and transnational social space, treating Europe as a (hypothetical, pseudo-) country in its own right. Such an approach differs considerably from previous studies on European solidarity in general where the analysis has focused on European solidarity within nation states. ${ }^{4}$ Treating European society as such reflects how Europeans are not only citizens of their home country but are also subject of the federal state called the European Union (Habermas 2011).

The paper is structured as follows: The first section provides a theoretical justification for comparing European and national solidarity. The second section presents some insights on the existence of a European society and thereby strengthens the premise of the paper. The data and the analytical strategy are introduced in section three. The paper closes with an empirical investigation into whether the theorized mechanisms are comparable at the two spatial levels and a discussion of the ramifications of the findings.

\footnotetext{
${ }^{3}$ For a brief discussion on the emergence and existence of a European society, see section Interlude as well as Ignácz and Vlach (forthcoming).

${ }^{4}$ For details on the analytical frame, please refer to the description in section Data and Methods.
} 


\section{Different but the Same: Theoretical Arguments on the Similarities Between National and European Solidarity}

The aim of the paper is to assess similarities between the support for European and for national redistribution. These similarities can be discussed based on two aspects: (1) whether solidarity at the European and at the national level are similar in their degrees; (2) whether support mechanisms are the same. As the similarities between attitudes towards national and European redistribution are not necessarily evident, it is important to reflect on reasons to expect similarities between solidarity at the two spatial levels and reasons not to.

\section{On similarities in the degree of support}

In the search for similarities and differences in the degree of support, the guiding questions are: Why could the degree of support between the two spatial levels (nation state and European level) be different? Why could it be the same? Here, one of the most plausible considerations is the institutional setting. Historically, nation states have a long-standing institutional infrastructure to tackle redistribution among its citizens. National welfare state institutions have a myriad of strategies and a broad range of instruments to tackle inequality (Korpi and Palme 1998; Gugushvili and Laenen 2021; cf. Bergh 2005; Jacques and Noël 2018). The relevance of these structures has been well documented with regard to the support for redistribution. While studies report mixed evidence of the so-called regime hypothesis, stating that the specific welfare regime type is decisive for welfare state attitudes (cf. Dallinger 2010; Schmidt-Catran 2016; Jæger 2006, 2009; García-Sánchez et al. 2020), overall, the policy setting and other circumstances have proven to be relevant for the support rates for redistribution. Moreover, support rates are often considered to be a feedback for the reigning institutional background (Brooks and Manza 2006). Thus, attitudes towards national-level redistribution reflect existing institutional structures and can be viewed as a feedback to it. In other words, the institutional setting in nation states contributes to the degree of support for national redistribution.

In contrast, policies (directly) targeting redistribution among Europeans at the European level do not yet exist. Thus, attitudes towards European-level redistribution reflect a hypothetical what-if setting without a feedback loop. There are historical reasons why there is no institution that directly subsidizes Europeans and why there are no intervening measures aimed at reducing inequalities between Europeans in the European Union. The European Union was initially devised as a monetary union, whereas decisions related to social policy were planned to stay under the jurisdiction of member states (de Witte 2015; Leibfried 2015). Instead, the EU's current legal framework offers two main solutions for transnational redistribution, which are in-line with respecting national sovereignty regarding social policy. On the one hand, the EU implements the open method of coordination (OMC) for the social policy field. The OMC spells out key objectives of the EU but is non-binding and serves solely as a guideline for national legislation. For example, new common principles for the labor market and social policy were recently introduced by the European Pillar of Social Rights (EPSR). However, the OMC and the EPSR explicitly respect the jurisdiction of nation states. On the other hand, the EU supports its member states to implement projects aimed at tackling regional inequalities through the European Social Fund. Here, the source of funding is European and transnational, 
but again both implementation and use of the fund are up to national and regional jurisdiction. Thus, the European Social Fund is essentially just another instrument for national redistribution. In sum: At the European level, coordination exists only among the member states; individuals are only indirectly beneficiaries of the fund (for details, see Börner 2020).

The above-described circumstances suggest that we can expect support rates for national and European redistribution to differ widely. However, the discussion of measures undertaken at the European level more and more refers to the comparison of national processes. In recent years, the term social Europe has become widely used. Social Europe stands for a conglomeration of national, transnational, and supranational programs, policies, and objectives that are concerned with channeling social policy topics into EU legislation (Ferrera 2017, 2014). Such a framing emphasizes similarities between national social policies and European policies (Börner 2020). Börner (2020) suggests that the Europeanization of the social policy field can be theoretically matched to T.H. Marshall's model on how social citizenship is the next step in social integration once universal political rights have been secured. While the current EU framework still lacks the universalism for a EU-wide social citizenship, Börner (2020) points out how we can expect solutions to resemble national institutions in form of a meta-welfare state in the future, such as a pan-European unemployment scheme, or a European minimum wage.

Furthermore, the feedback loop observed for nation states can perhaps - even if in a rudimentary stage - be spotted at the European level. Scholars have underlined how to some extent Europeanization processes resemble processes of national state building at the turn of the $20^{\text {th }}$ century. In particular, Börner and Eigmüller (2018) point out that the emergence of national social policy institutions in top-down nation-building processes such as the Austro-Hungarian Empire demonstrates the potential of European-level welfare policies in the future. They underline that the actors, i.e., Europeans, play an important interactive role in national building processes. This suggests that the degree of support for the principles of redistribution could pave the way for EU-wide policies. Moreover, the level of support for European redistribution could be on par with the degree of support for national redistribution. In fact, Gerhards and colleagues (2019b) have already briefly investigated this and have concluded that the degree of support is indeed comparable at the two spatial levels. This leads to the first hypothesis:

H1: The degree of support for the national redistribution and the European redistribution is comparable.

\section{On the similarities between mechanisms}

Beyond the degree of support, it is important to clarify the similarities between the mechanisms that explain the support for national and European redistribution. More generally speaking, the question arises whether there are similar factors fostering the principle of redistribution within different social spaces. Do the same factors influence the attitudes toward different territorial redistribution at the individual level? It is important to investigate which factors raise support rates as these factors pinpoint social alliances and dissent in the public discourse about social policy measures. 
Studies focusing on national redistribution suggest that attitudes are split along various cleavages (Svallfors 1997; see Alesina and Giuliano 2011) and that the interplay of these cleavages in societies is a reason for specific configurations in welfare state institutions (Henjak 2010; Armingeon and Bonoli 2006; Esping-Andersen 1990). At a certain point in time, when welfare states started to emerge, there was a certain configuration of power among the social divides through which the dominant groups contributed to the make-up of welfare state institutions according to their interests. Then, once such welfare state institutions are established, the social divides are expected to uphold their legitimacy by means of feedback loops (Arts and Gelissen 2001).

In contrast to the degree of support, it is less clear what to expect of social divides among different social spaces. At the national level, different social cleavages already exist. The cleavage structure within each nation state is unique. If we add to the mix the European social space, the situation becomes even more complicated. National cleavages and mechanisms connected to them serve as the initial compass to assess the similarities between cleavages in the different social spaces. In a second step, we will consider whether these mechanisms carry over to the European level.

Initially, research on the relevance of cleavages for national welfare state attitudes closely followed Lipset and Rokkan's (1967) cleavage theory and investigated how class differences divide society in its support for a welfare state (Brooks and Svallfors 2010; Andreß and Heien 2001; Svallfors 2004). Studies have shown that beyond the class-based division motivated by self-interest, ideological and cultural factors contribute to explaining attitudes towards redistribution (Blekesaune and Quadagno 2003; Gelissen 2000), as does age (Bonoli and Häusermann 2009; Andreß and Heien 2001). Accordingly, this paper will take into account structural and cultural divides in national spaces and then consider whether these divides can be detected at the European level, too.

Structural cleavages imply socio-economic, i.e., class-based, social divides. Redistributive policies aim to curb the income of affluent individuals and subsidize those in the lower strata of society. Self-interest can therefore explain the connection between the individual's socio-economic position and their attitudes towards redistribution. The lower strata of society benefit from redistributive policies and therefore due to self-interest, their class position contributes to explaining their inclination to support redistribution. Regarding attitudes towards national redistribution, research has consistently provided evidence that one's structural position is an important factor: the weaker a social structural position is, the more likely someone is going to support national redistributive measures (Svallfors 2004; Andreß and Heien 2001; Andersen and Curtis 2015; Andersen et al. 2021).

At the European level, the prominence of self-interest is less evident. In fact, self-interest can operate in two opposing directions. On the one hand, individuals from the lower strata would benefit from European redistribution. This suggests support for European redistribution. On the other hand, individuals may also fear that their already low subsidies will be cut if redistribution is introduced at the European level. So, it is also reasonable to assume that the lower strata of society may oppose a European redistribution more than the higher ones. Studies adopting the latter argument did not provide strong evidence for it (Berg 2007; Mau 2005; Gerhards et al. 2016). On the other hand, studies suggesting that self-interest plays a similar role at 
the European level as at the national level provided evidence that the individuals' social influence on support for European redistribution is also negligible (Meuleman et al. 2020; Gerhards et al. 2019a).

Cultural cleavages refer to a social divide along the lines of ideological and value-based sentiments. Redistributive policies have a value-based foundation linked to egalitarianism and equality. Hence, an individual whose disposition matches the ideological underpinnings of redistributive policies will also support those policies. Furthermore, drawing on the epistemological foundations of solidarity (Bayertz 1999), a sense of community and connections to others can also motivate people to support redistribution. Studies investigating the relevance of ideology for support for national redistributive measures conclude that individuals with egalitarian views do exhibit greater support (Lewin-Epstein et al. 2003; Blekesaune and Quadagno 2003). In contrast, the role of national identity and the sense of belonging for national welfare state attitudes is more contested. Scholars have demonstrated that either national identity plays only a moderate role for universal attitudes (Johnston et al. 2010), or they have provided evidence that national identity fosters welfare chauvinism and restricts (support for) redistributive policies (Wright and Reeskens 2013).

On the one hand, at the European level, the role of cultural cleavages may play out similarly as at the national level. The mechanisms expected to foster support for European redistribution should be similar to mechanisms observed at the national level. Political value orientation and the leftist anchoring in egalitarian values and a strong sense of community at the European level both motivate support for European redistribution. On the other hand, given the hypothetical nature of a European redistribution, cultural divides in terms of value-based orientation and sense of community can be expected to have a stronger influence than structural divides, whereas at the national level structural divides are dominant. There is, indeed, evidence pointing in that direction. Cultural factors, both in terms of egalitarianism and equality as well as identity, have been recognized as prominent indicators in explaining attitudes towards European redistribution (Kuhn et al. 2018; Gerhards et al. 2019a; Ignácz 2019; Meuleman et al. 2020). Most notably, self-identification with Europe plays a pronounced role and is considered an important driver of attitudes (Nicoli et al. 2020; Kuhn et al. 2018; Kuhn and Nicoli 2020). Such trends tie in well with the discussion on a newly emerging cleavage between cosmopolitans and communitarians (Kriesi 1998; Kriesi et al. 2006; Grande and Kriesi 2015; Zürn and Wilde 2016).

Beyond these considerations, we can find further reasons to expect similar cleavages to emerge within nation states as well as in a European society in the work of Karl Deutsch (1953, 1960). The main point of Deutsch's theory is that the micro-level interactions between individuals provide the basis of social processes and thus the foundations of societies. Thus, transnational interactions provide the basis for a transnational society. Favell and Guiraudon (2011b: 5 ) highlight the essence of the theory elaborately in the following passage:

In these terms, it was possible to consider measuring the everyday cross-border interactions of European elites, policy actors and (potentially) everyday citizens, as an indicator of cross-border integration-a process that might one day form a European society as the sum of all the European transactions, and which would be a parallel process to the historical dynamic that formed societies on a national scale. 
In the following, two arguments underlining the plausibility of similar mechanisms at the national and the European level are presented. Both of the arguments are based on transactionalist theory. The first argument is grounded in the network application of Deutsch's transactionalist theory (Mann 1998; Deutschmann et al. 2018). Scholars of this school argue that the transactionalist theory implies that the initial territorial confinement of interpersonal interactions within nation states is merely an outdated convention. National borders can effectively be seen as an artificial, politically construed obstacle. As soon as institutional settings foster interactions beyond nation states, the social processes which were confined by national borders expand into a wider social space. National and European processes are made up of the same units: social interactions. In this rather simplistic reading, European processes would be simply territorial expansions of national processes. From this follows that national divides are carried over to the European level. Such an interpretation underlines the paper's premise well: national mechanisms fostering national solidarity are carried over to the European level and become European mechanisms to foster European solidarity.

The second argument comes from scholars with a micro-perspective on Europeanization and a focus on agent-based processes. As part of the quest to verify the existence of a European society, sociologists have investigated how national social structures spill over into the European social space (Kuhn 2015; Mau and Mewes 2009). ${ }^{5}$ They found that the power structure in social hierarchies within nation states also reflects the degree of engagement in transnational practices. As a consequence, the inequalities within national societies are reproduced on a transnational scale. Following this approach, we could assert that social divides related to national solidarity are carried over to social divides related to European solidarity.

In short, the main message of these two arguments is that we can expect similarities between national and European level mechanisms. That is, the core of the arguments deals with the question of how national level processes are transported to the transnational, European level. Both arguments emphasize the similarity of the structures of European and national processes and therewith provide theoretical ground to connect European and national-level mechanisms for support of redistribution. Furthermore, historical reflection on the processes that existed when nation states and welfare states were just being formed can give us insight into the processes currently taking place at the European level (Börner 2015).

All in all, previous literature suggests that attitudes towards European and national redistribution share many core mechanisms while the prominence of these mechanisms may differ for the two spatial levels. Whereas structural cleavage is consistently important for national redistribution, ideology as value-based sentiments linked to egalitarianism and equality and identity as sense of community and connections to others appear to be important factors for European redistribution. If we find that under the same controlled circumstances the same factors emerge for European redistribution as they do for national redistribution, this could indicate that national mechanisms are reproduced at the European level. This leads to the second hypothesis:

\footnotetext{
${ }^{5}$ Note that the spillover described here is not identical with the Haasian neofunctionalist understanding of spillover effects for European institutions (cf. Favell and Guiraudon 2011b).
} 
$\mathrm{H} 2:$ The mechanisms for the support for national redistribution and European redistribution are comparable.

\section{Interlude: Social Integration in the European Union in Light of an Emerging European Society}

So far, this paper has not contested the notion of a European society. In fact, the assumption that a European society exists in some form is a central assumption of the paper. In the following, I will briefly put forth some arguments in favor for that assumption. There are two key points to the argument: First, European integration exhibits signs of social integration similar to that of social integration in national societies. Second, scholars in the field of sociology of Europeanization provide encouraging evidence that a transnational European society is emerging in the European social space.

The question of social integration has engaged sociologists since the discipline's earliest days, albeit independent of the level of the social space. Founders of the functionalist school of thought (i.e., Durkheim, Tönnies, and Parsons) have commonly identified two ideal ways in which societies organize themselves. One way is non-hierarchical, with a lack of an interdependent organization of tasks, where group membership is distinct, and where cooperation is dominant. The other way builds on a clear societal division of labor combined with a competitive nature of social order. Such a dichotomy of the way societies organize themselves is conceptualized by Durkheim (1933[1893]) with concepts like mechanical and organic solidarity, or resonates with Tönnies' (2005[1935]) terms Gemeinschaft (community) and Gesellschaft (society). Modern nation states are seen as social organizations with differentiated functionality but with some features of community, e.g., cooperation, a sense of group identity (Clark 1973). Considering such a theoretical division of social systems, Deutsch (1979: 243) assessed the early stages of European integration as being functionally specific, resembling rational organizations. ${ }^{6}$ While he did hint to the notion that European integration has the potential to pave the way for a more community-like social organization, with more diffuse functionality, he did not expect this to actually take place. Yet, in the $21^{\text {st }}$ century, Deutsch's expectations do not stand up to the facts. In 2021, the European Union, with its 27 member states, ${ }^{7}$ has a broadening agenda of not only a competitive nature, but of cooperation, collaboration, and mutual support, thus indeed exhibiting features of a community. As such these processes at the European level resemble social integration processes contributing to the emergence of national societies.

There is also a growing body of literature dealing with how a European society is empirically emerging in the European social space as individuals in different national societies are transnationally connecting with each other. European society in singular form means that Europeans take part in affairs reaching beyond their own national borders, and that they are able to, willing to, and interested in engaging with others across borders in Europe (Teney and Deutschmann 2018). Scholars studying European society focus on one of three main aspects to find indicators for the existence of a European society: (1) cognitive, (2) structural, or (3) affective aspects. This means that if (1) Europeans have a European frame of reference, (2) engage in transnational

\footnotetext{
${ }^{6}$ Deutsch referred to the state of European integration in 1962.

${ }^{7}$ The United Kingdom formally exited the European Union on January 31, 2020.
} 
practices, or (3) self-identify as European, they indicate the existence of a European society. On the one hand, scholars have found evidence that other European countries serve as a reference point for individuals and that this newfound point of reference also shapes social structural trends (Delhey and Kohler 2005; Goedemé et al. 2019; Lahusen and Kiess 2019; Whelan and Maître 2009). However, the European society still has room to grow: scholars report a relatively low number of individuals who engage in transnational practices (Kuhn 2015: 37-38) and low rates of a European middle class, i.e., those who are members of the national middle class and identify primarily with Europe (Díez Medrano 2010). On the other hand, other scholars understand European countries as interlinked yet argue that they should not be dealt with as one single unit (Spurk 2014). Thus, while the existence of a European society is disputed, there is a growing consensus that a social organization exists in broader spatial terms beyond nation states. ${ }^{8}$

\section{Data and Methods}

To investigate generalized attitudes towards national and European redistribution, the paper utilizes the Transnational European Solidarity Survey (TESS). TESS was carried out in 13 EU countries ${ }^{9}$ between May and November of 2016 using CATI-method telephone interviews. Respondents were registered national citizens aged 18 or older at the time of the survey. The primary objective of the TESS was to measure public opinion on national, European, and global solidarity. The data set fits the agenda of this paper well. ${ }^{10}$ After listwise deletion, a total of 9048 respondents were included in the analysis presented in this paper.

The paper employs items in the analysis that capture survey respondents' opinions on whether inequalities should be reduced between people within Europe and in their own country. Survey research methodology has developed numerous questionnaire items to study attitudes towards (national) redistribution among the general public. These items are established and are widely used in cross-national surveys. ${ }^{11}$ These established measures were utilized during the development of the TESS. The item that focuses on national redistribution was adapted to its current form from well-established and validated surveys (e.g., ESS Round 4: European Social Survey 2016; ISSP Research Group 1999). The item wording in the questionnaire is as follows:

\footnotetext{
${ }^{8}$ For a more detailed overview of the theoretical discussion, see Ignácz and Vlach 2021 (forthcoming).

${ }^{9}$ TESS was carried out in Austria, Cyprus, France, Germany, Greece, Hungary, Ireland, the Netherlands, Poland, Portugal, Spain, Slovakia, and Sweden. The survey covers a broad spectrum of EU countries along the following dimensions: (a) whether a country formerly received or currently receives financial aid in relation to the Eurozone crisis; (b) whether the country is a member of the currency union or not; (c) which welfare state regime the country belongs to (i.e., liberal, social-democratic, conservative, Mediterranean, post-socialist); (d) duration of membership (i.e., founders of the European Economic Community (EEC), or new EU Member States).

${ }^{10}$ For details on the survey and the exact wording of the items discussed in the paper, see the TESS codebook (Gerhards et al. [unpublished]).

${ }^{11}$ E.g., European Social Survey (ESS), International Social Survey Programme (ISSP), World Value Survey (WVS).
} 
People have different views on what the [NATIONAL] government should be responsible for. Please tell me for each of the following statements whether you totally agree, tend to agree, tend to disagree or totally disagree.

The [NATIONAL] government should reduce income differences between the rich and poor in [COUNTRY]. (Gerhards et al. [unpublished]: 22)

At the time of fielding the TESS, there was no established measure for generalized attitudes of European redistribution that could serve as the counterpart to attitudes towards national redistribution at the European level. So the established national item was altered as little as possible in the TESS survey to then target attitudes towards European redistribution in order to achieve validity and reliability. The expression related to redistribution, sentence syntax and the grammatical structure of the item is unchanged compared to the established item measuring attitudes towards national redistribution. However, the spatial reference and the actor executing redistribution were modified. Instead of the national government, the European Union is the acting institution to reduce inequality; also, the reduction does not only occur within national borders but within the borders of the EU. The item wording in the questionnaire is as follows:

Now please don't think about [COUNTRY], but about the European Union in Brussels and its responsibilities. Please tell me for each of the following statements whether you totally agree, tend to agree, tend to disagree or totally disagree.

The European Union should reduce income differences between the rich and poor in the EU. (Gerhards et al. [unpublished]: 26)

Both items in question are measured by four-point Likert scales, where the lowest value means respondents totally agree with the statement of the item, while the highest value means that they totally disagree with it. For the sake of this analysis, the items were reversed and scaled from 0 to 3 to ease the interpretation: higher values mean that respondents agree more with the statement in question.

A set of independent variables was chosen to map structural and cultural cleavages. Structural cleavages are captured by several variables that reflect the socio-economic status of individuals. The analysis aims to capture socio-economic status both following Bourdieu's tradition with cultural and economic capital and an occupational class tradition based on the EGP class scheme (Evans 1992). In Bourdieu's tradition, status is measured by the highest level of education and household income divided into deciles. Occupational class based on the EGP class scheme (Evans 1992) is employed to operationalize social class. The TESS dataset lacks variables to elaborately capture labor market status. Therefore, this paper makes the attempt to represent one perspective on social class by dividing respondents based on their employment status (1 unemployed, 0 - not unemployed). Two variables capture mechanisms related to cultural cleavages: Political value orientation was measured by the established index of self-placement on a left-right scale (Lo et al. 2014), which was centered for better interpretation. Affectual identification with the respondents' nationality and nation state and with Europe were measured as a dummy variable ( 1 - yes, 0 - no). Furthermore, the analysis controls for the number of children in the household and age and gender of the respondents, as these factors can potentially be connected to the mechanism of self-interest. ${ }^{12}$

\footnotetext{
${ }^{12}$ For details on the exact wording of the items, see the TESS codebook (Gerhards et al. [unpublished]).
} 


\section{Analytical strategy}

An important premise of the paper is that individuals of European member states are part of one single society when discussing European solidarity. In a way, the EU is identified as a pseudo-country for the purpose of the analysis. Thus, all responses regarding European redistribution are pooled together. Parallel to this, national solidarity is anchored in nation states, thus individuals within one nation state are pooled together for the analysis. Such duality is maintained throughout the empirical part of the paper.

From this follows that in order to assess the similarities in the degree of support, the average support for national redistribution by each nation state must be contrasted with the average support for European redistribution for all Europeans in the sample. To assess the similarities between mechanisms, the prevailing cleavage structure needs to be explored. To this end, the set of independent variables described above is included in the analysis to identify the cleavage structure within nation states and within Europe as a pseudo-country. To compare the cleavage structure for attitudes both at the national and at the European level, the operationalization of the cleavages needs to be identical at the two levels. So the analysis is conducted on the national samples and then on the European sample when the pooled data set is a stand-in for the pseudocountry of Europe. Yet, the operationalization also needs to be mindful of the national and transnational meaning of the cleavages for attitudes towards national and European redistribution. In particular, household income and identification differ slightly at the two spatial levels. Analysis focusing on attitudes towards national redistribution will include a household's position relative to the national income distribution of the survey population and national identity. In contrast, where the dependent variable includes attitudes towards European redistribution, a household's relative position compared to the European income distribution of the survey population ${ }^{13}$ and European identity are analyzed.

The methodological toolbox used for the cleavage analysis is structural equation modelling (SEM). The SEM framework has advantages over an ordinary least square approach (both pooled or multilevel) because SEM is much more flexible in terms of model specification. Parameters can be easily constrained in the regression models for statistical testing. In particular, SEM allows for regression coefficients to be set as equal or to assume certain values, and this technique can be applied to both simple pooled models and models with a multiple group configuration. The SEM framework also has elaborate fit indices that help discern whether certain parameters of regression models are equivalent.

To assess the similarities in cleavage structures, the paper employs a two-step analytical strategy. In both steps the same path diagram is modelled (see Figure 2), but with different model setups and different samples. However, the values of the parameters - labelled a-o in Figure 2 - are to be compared in the two steps. For example, is the value for the coefficient $i$, which measures the effect of being unemployed, the same in Step 2 as in Step 1 when the spatial reference has shifted? In detail, this means that in the first step the cleavage structure that overarches nation states will be identified. If a uniform cleavage structure cannot be identified, then

\footnotetext{
${ }^{13}$ Papers rarely employ transnational income thresholds to categorize the income of individuals (for an exception, see Heidenreich 2016). However, this approach matches the theoretical framework of the paper very well: a household's relative position compared to European income distribution reflects the sentiment of the existence of a European society.
} 
a meaningful cleavage structure for a subset of countries needs to be located. In other words, the first analytical step is to identify universal mechanisms forming attitudes towards national redistribution by achieving structurally invariant models. To this end, multiple-group regression analysis is employed to assess how the independent and control variables affect attitudes towards national redistribution. This approach is different from the established pooled OLS regression, where the country context is uniformly controlled for with country dummies or country fixed effects, i.e., the slopes for the individual indicators are uniform across all units of analysis. In a multi-group regression analysis, each of the parameters can be individually fixed or constrained. Thus, this technique enables us to better assess effects across multiple country samples and, in turn, to see patterns of national cleavage structure more clearly. A systematic approach was chosen, starting with the least constrained model where all the parameters of the independent variables were set free across the 13 countries, i.e., for each country the coefficients were let to vary completely free. Then more and more constraints were introduced in the models, i.e., the values of certain parameters were set equal for all countries. Newly introduced constraints were accepted only if incremental fit indices (RMSEA, SRMR, CFI, BIC) improved. In short, this first step investigates the effect of the independent variables on attitudes towards national redistribution; the aim is to keep the effects of each parameter equal for all countries.

In the second step, the identified national cleavage structure is transferred to the European level. Here, the analysis tests whether the cleavage structure established for nation states holds for a European society. To achieve this, values of the model parameters from the final national multi-group model are the values the model parameters are set to in the model explaining attitudes towards European redistribution. As already explained above, when we talk about attitudes at the European level, the analysis treats respondents as if they were members of the same society. Accordingly, responses are pooled together for this single regression analysis. The parameter values are fixed to the coefficient values measured in the final multi-group model for national redistribution. In Figure 2, this means that the value of $i$ associated with the effect of being unemployed on supporting national redistribution in the first step is the value to which the i-parameter is fixed in this second step, i.e., to test the effect of being unemployed on support for European redistribution. If the models for European redistribution reflect good fit measures when the parameters are constrained to the values observed at the national level, then this is an indication that the same cleavage structure exists at the European level. 
Figure 2: Path diagram for core model

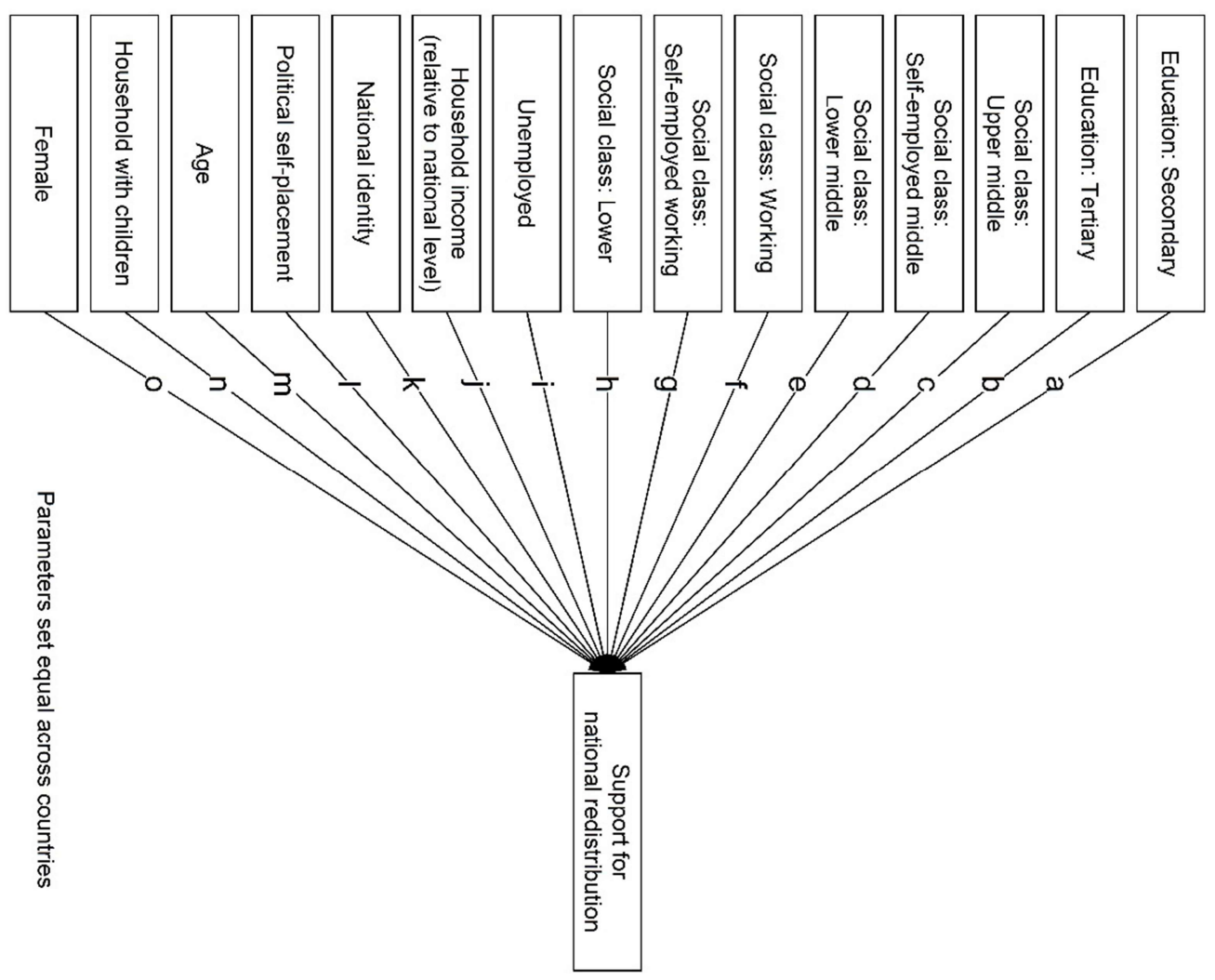

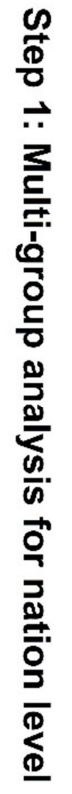

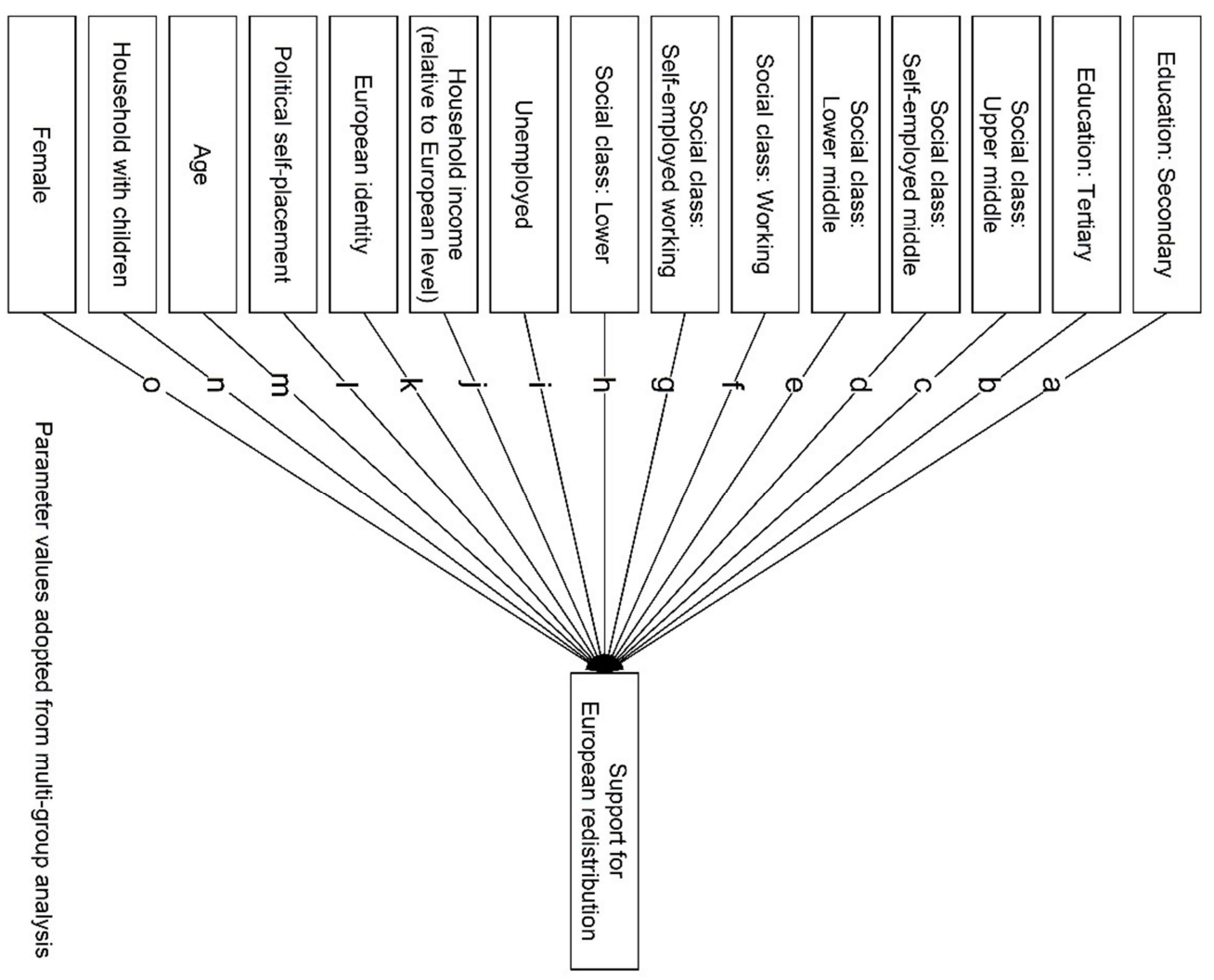

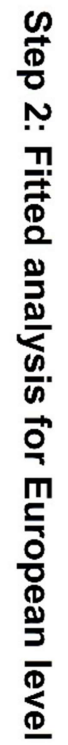

Source: Own depiction. 


\section{Results}

\section{Similarities in the degree of support}

One of the aims of the paper was to assess whether the degree of support for redistribution is similar at the national and at the European level. Accordingly, the H1 hypothesis formulated the expectation that the degree of support for the national redistribution and the European redistribution are comparable, as processes akin to nation building can be observed at the European level. To evaluate the hypothesis, the average degree of support for national and European redistribution was assessed. To this end, Figure 3 shows the average support rates for national and European redistribution. The value for each country refers to country averages for support rates for national redistribution (highlighted in orange in Figure 3), while the value for the EU stands for the average support rates towards European redistribution among Europeans in the sample (highlighted in blue in Figure 3). These figures reflect the degree of support for redistribution in nation states and the degree of support in the European social space when the European social space is treated as a pseudo-country. In general, all support rates are high; the values are above 2 on a scale from 0 to 3 . This means that on average individuals tend to agree with the goal of reducing inequalities within society. Attitudes towards European redistribution are no exception. However, support rates for European redistribution are lower than the average for national redistribution in most countries. The only exceptions are the Netherlands, Poland and Sweden. In these countries, the average support rates are lower for national redistribution than for European redistribution in Europe. These results underline that high support rates need not necessarily reflect already existing and established institutions. This suggests that the willingness to reduce inequalities at the European level is already taking shape in the European society. 
Figure 3: Degree of support for European and national redistribution, weighted averages

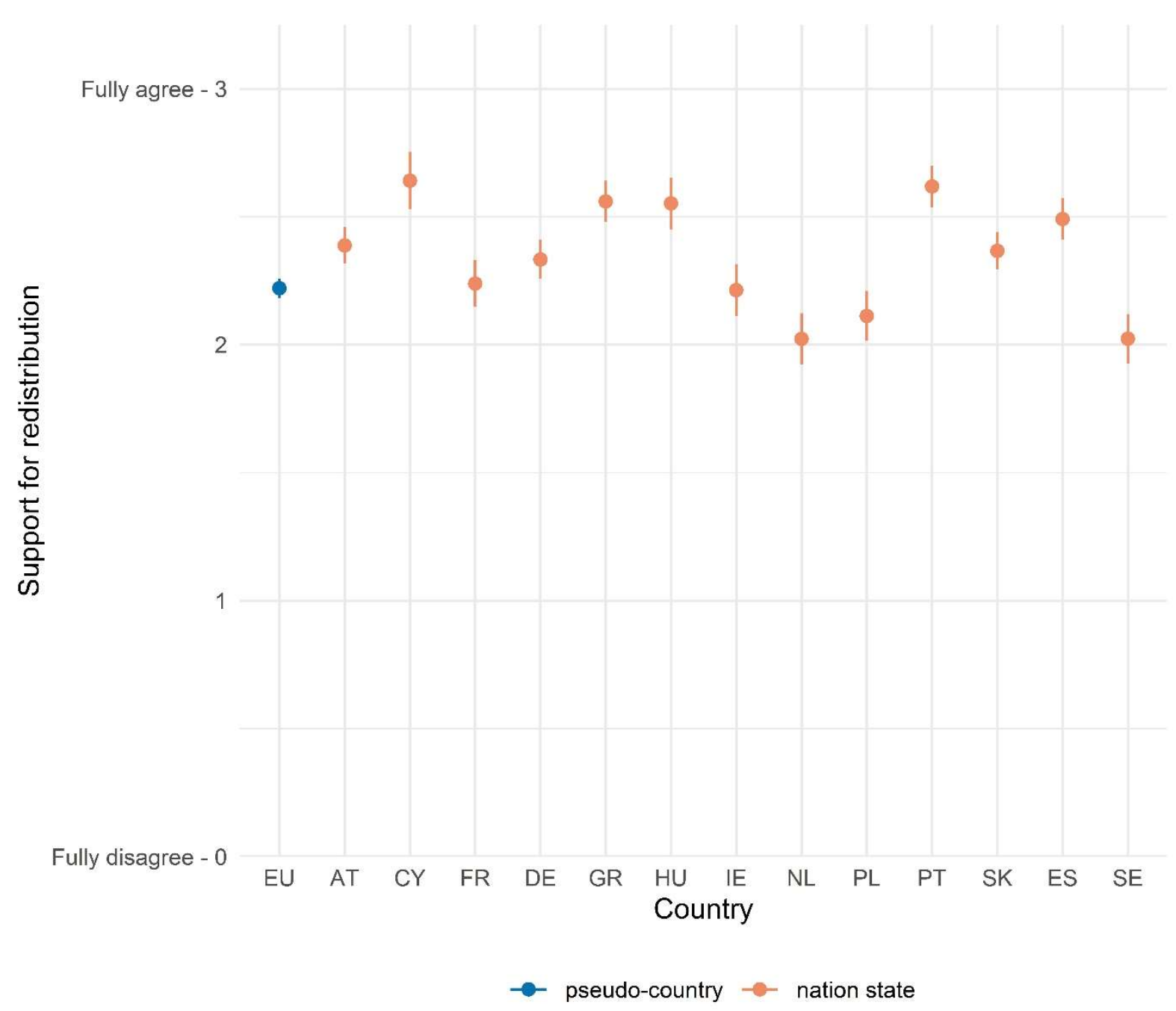

Source: TESS 2016; $N=9048$.

\section{Similarities between mechanisms}

Beyond assessing the similarities in the degree of support for national and European redistribution, the paper's aim is to consider whether there are similarities between the mechanisms that foster support for redistribution. The H2 hypothesis states that we can expect the mechanisms for the support for national redistribution and for European redistribution to be comparable. This means that the national cleavage structure underlying the support rates for national redistribution and the European cleavage structure underlying support for European redistribution need to be examined and contrasted with one another. To this end, a two-step analysis is employed. As a first step, national cleavage structures need to be identified across all countries. This will serve as the reference point to then assess the cleavage structure for European redistribution in Europe in a second step. 


\section{Step 1: Identifying the national cleavage structure for national redistribution}

A multi-group regression analysis is employed to gauge the cleavage structures for attitudes towards national redistribution. This essentially means that respondents from each country were separated from each other but values of the (certain sets of) parameters, i.e., unstandardized coefficients, were set to equal when running the regression analysis. Table 1 provides an overview of the unstandardized regression coefficients of the multiple-group regression analysis conducted for the 13 TESS countries for the final and best-fitting model of the multi-group of attitudes towards national redistribution. The best model fit was achieved when almost all of the independent and control variables were equal across all countries. The only effect that could not be kept equal across all countries was political value orientation. Good fit was only achieved when some countries were clustered together based on the effect of political value orientation. In total, three country groups were identified: Continental European, post-socialist, and Mediterranean countries (with Ireland as a guest). Within these clusters, the effect of political selfplacement is equal. ${ }^{14}$ Thus, partial invariance was achieved. From this follows that in Table 1 all unstandardized coefficients, except for the political value orientation, share the same value for all of these countries.

Table 1 reflects that structural cleavages are relevant for attitudes towards national redistribution, as the majority of variables representing structural cleavages significantly affect the dependent variable. Across the surveyed European countries, the socioeconomic position affects the support for national redistribution. Those who have an affluent position in their national societies oppose national redistribution more. In contrast, those with weak structural positions are more supportive of national redistributive measures. This is reflected in the fact that those with tertiary education support, on average, national redistributive policies less than those who have primary education or less $(b=-0.105) \cdot{ }^{15}$ Members of lower social classes have a significantly higher supportive stance towards national redistribution. The tendency is similar for those in working class occupations: they support national redistribution on average 0.119 points more than those in the upper class. The effect of household income is the most significant, negative effect $(b=-0.03)$. Individuals from high-income households reject national redistribution on average more than those who live in low-income households.

Furthermore, cultural cleavages play a mixed role. First, identity does not play a role for attitudes towards national redistribution; it is insignificant (and even, if let to vary across countries). Second, political value orientation stands out in the model. The coefficient is the only one where country constraints did not hold and only partial invariance could be achieved. In postsocialist countries, the self-placement on the left-right scale is of lesser importance, as the effect $(b=-0.015)$ is significant only at a 0.05 level. Given that the left-right labels in the political discourse often do not match the actual ideological position in post-socialist countries, this is a plausible finding. In Mediterranean countries (including Ireland), we can observe a moderate effect $(b=-0.068)$, while the effect is the strongest in Continental European countries $(b=-0.125)$. The direction of the effect is uniform: the more individuals situate themselves on the right on

\footnotetext{
${ }^{14}$ For details about the main tested models, see Table A2 in the Appendix.

${ }^{15}$ Those with tertiary education support national redistributive policies on average 0.0105 points less than those who have "primary or less education".
} 
the value scale, the less they support the notion of national redistribution. Overall, the findings mirror the mechanisms described in the theoretical section.

Table 1: Determinants of attitudes towards national redistribution, unstandardized regression coefficients from multi-group structural equation model

\begin{tabular}{|c|c|c|c|}
\hline & Continental & Post-socialist & Mediterranean \\
\hline \multicolumn{4}{|l|}{ Education: Primary or less (Ref.) } \\
\hline Secondary & & 0.034 & \\
\hline Tertiary & & $-0.105^{\star}$ & \\
\hline \multicolumn{4}{|l|}{ Social class: Upper (Ref.) } \\
\hline Upper middle & & 0.057 & \\
\hline Self-employed middle & & -0.008 & \\
\hline Lower middle & & 0.057 & \\
\hline Working & & $0.119^{\star \star *}$ & \\
\hline Self-employed working & & 0.053 & \\
\hline Lower & & $0.105^{\star}$ & \\
\hline Unemployed (0/1) & & 0.048 & \\
\hline Household income relative position (in deciles) & & $-0.03^{\star * *}$ & \\
\hline Political left-right scale (centered) & $-0.125^{\star * *}$ & $-0.015^{\star}$ & $-0.068^{\star * *}$ \\
\hline Identity & & -0.008 & \\
\hline Female $(0 / 1)$ & & $0.08^{\star * *}$ & \\
\hline Age (in 10 years) & & $0.038^{\star \star \star}$ & \\
\hline Household with children $(0 / 1)$ & & -0.008 & \\
\hline AIC & & 22569.332 & \\
\hline $\mathrm{BIC}$ & & 22782.641 & \\
\hline CFI & & 0.934 & \\
\hline RMSEA & & 0.022 & \\
\hline SRMR & & 0.042 & \\
\hline
\end{tabular}

Source: TESS 2016; N=9048. Significant effects in bold.

\section{Step 2: Similarities in national and European cleavage structures}

The second step of the analysis on cleavages is to investigate whether the national cleavage structure is carried over to the European level. For this investigation, we take a look at how the national cleavage structure, previously validated in 13 nation states, appears if we consider all of our respondents as parts of one European society. As the final model solution for national redistribution consists of three sets of parameters, the aim of the analysis was to assess which one of these three sets of parameters match the model for European redistribution.

Table 2 portrays the fit indices for the fitted models. Two different sets of model configurations were tested. In the first configuration, theoretically truer models are employed, meaning 
that only those parameters are included in the models that were also used to assess the cleavage structure for support towards national redistribution in the previous step. A second configuration was also run to test for contextual effects by including country dummies as unconstrained controls. Theoretically, adding country dummies as controls can be partially contended, considering that countries are regions on a European scale. However, introducing country dummies into the analysis defies the logic of the thought experiment when we treat Europe as a pseudo-country. As Table 2 shows, this additional control improved the fit of all models tested. This is not surprising, as countries do mitigate mechanisms related to European solidarity (Gerhards et al. 2019b). Hereinafter, only the models from the first configuration are discussed.

Overall, the unconstrained models provide a point of reference regarding whether constraining the parameters according to the models of national redistribution improves our model. In other words, the unconstrained model serves as a baseline for the other models.

Table 2: Fit measures in the different models with attitudes towards European redistribution

\begin{tabular}{cccccccc}
\hline Model & $\chi^{2}$ & df & AIC & BIC & CFI & RMSEA & SRMR \\
\hline $\begin{array}{c}\text { Model 0 } \\
\text { Unconstrained }\end{array}$ & 0 & 0 & 23972.329 & 24086.094 & 1 & 0 & 0 \\
\hline $\begin{array}{c}\text { Model A } \\
\text { Fitted (Western Europe) }\end{array}$ & 356.043 & 15 & 24298.372 & 24305.482 & 0.619 & 0.05 & 0.054 \\
\hline $\begin{array}{c}\text { Model B } \\
\text { Fitted (Eastern Europe) }\end{array}$ & 312.162 & 15 & 24254.491 & 24261.602 & 0.668 & 0.047 & 0.047 \\
\hline $\begin{array}{c}\text { Model C } \\
\text { Fitted (Mediterranean Europe) }\end{array}$ & 130.412 & 15 & 24072.741 & 24079.852 & 0.871 & 0.029 & 0.033 \\
\hline $\begin{array}{c}\text { Model 0 } \\
\text { Unconstrained }\end{array}$ & 0 & 0 & 23557.06 & 23756.148 & 1 & & 0 \\
with country controls & & & & & & & \\
\hline $\begin{array}{c}\text { Model A } \\
\text { Fitted (Western Europe) } \\
\text { with country controls }\end{array}$ & 306.855 & 15 & 23833.915 & 23926.349 & 0.779 & 0.046 & 0.037 \\
\hline $\begin{array}{c}\text { Model B } \\
\text { Fitted (Eastern Europe) } \\
\text { with country controls }\end{array}$ & 188.129 & 15 & 23715.189 & 23807.623 & 0.869 & 0.036 & 0.026 \\
\hline $\begin{array}{c}\text { Model C } \\
\text { Fitted (Mediterranean Europe) } \\
\text { with country controls }\end{array}$ & 38.875 & 15 & 23565.935 & 23658.369 & 0.982 & 0.013 & 0.013 \\
\hline
\end{tabular}

Source: TESS 2016; $N=9048$.

Of the three country groups tested, the factors influencing attitudes towards European redistribution match closest with how factors influence attitudes towards national redistribution in the 
Mediterranean countries. When the parameters were constrained to the values of Mediterranean countries, the change in AIC and BIC was insignificant; it was even smaller when the country context was controlled for. This is further underlined by the incremental fit indices: CFI, RMSEA, and SRMR.

A noteworthy result of the models is that the effect of identity is surprisingly weak, despite previous studies reporting the prominence of European identity for attitudes towards European redistribution. To make sure that the constraints introduced in the model are not the reason for its weak effect, a version of the model was also fitted when (European) identity was not constrained to the value of the effect of national identity on support for national redistribution from the previous step. This last set of models is not depicted in Table 2 as no major changes could be detected in fit measures. Allowing identity to be included into the model as unconstrained did not contribute to better model fits. In fact, identity remained an insignificant effect in all the models.

The cleavage structure for European redistribution was assessed by constraining all model parameters. This means that the values of the unstandardized coefficients (and hence the interpretation of the coefficients) are identical with coefficients for Mediterranean countries in the multi-group model for national redistribution because they are fixed to the values in the nation states models from the first step. So, beyond the formal assessment of the models as discussed above, it is more meaningful to focus our attention to the standardized coefficients for each country as well as the European pseudo-country. Despite the unstandardized coefficients being constrained to be equal, the standardized coefficients still vary within a country due to different distributions of the dependent and independent variable. Such an analysis allows us to inspect the relative effect sizes of attitudes towards national and European redistribution. For this, standardized coefficients of the two analytical steps are inspected. This provides further insight into what the cleavage structure looks like for the two spatial levels. Figure 4 depicts the absolute value of the standardized coefficients from the final models for both attitudes towards national redistribution and attitudes towards European redistribution. The values associated with countries are the standardized coefficients based on the models presented in Table 1. The values marked by the country labels are the value of standardized coefficients for each country based on the final model from step $1 .{ }^{16}$ The values marked with "EU" are the standardized coefficients from the model where the values of coefficients are constrained to the parameter set of Mediterranean countries. Thus, the graph fuses the results of models from the two steps with dependent variables but with the same set of independent variables. Green indicates a positive direction of the effects, light red indicates a negative effect. The transparency of the shapes reflects whether the standardized coefficient is significant or not. The size of the shapes reflects the rank of the effect in absolute terms, the bigger the stronger. For the sake of a clear overview, only the values of the three strongest coefficients for each country are provided in the graph. All of the depicted effects are also significant. For a full overview of the standardized coefficients, refer to Figure A1 in the appendix.

\footnotetext{
${ }^{16}$ Please note that Table 1 depicts the unstandardized coefficients, which are equal across all countries. However, the standardized coefficients are not constrained to be equal in a multi-group setting, hence there is a set of standardized coefficients particular to each country. This is what Figure 4 makes use of this.
} 
Figure 4: Overview of prominent determinants of attitudes towards redistribution, standardized coefficients

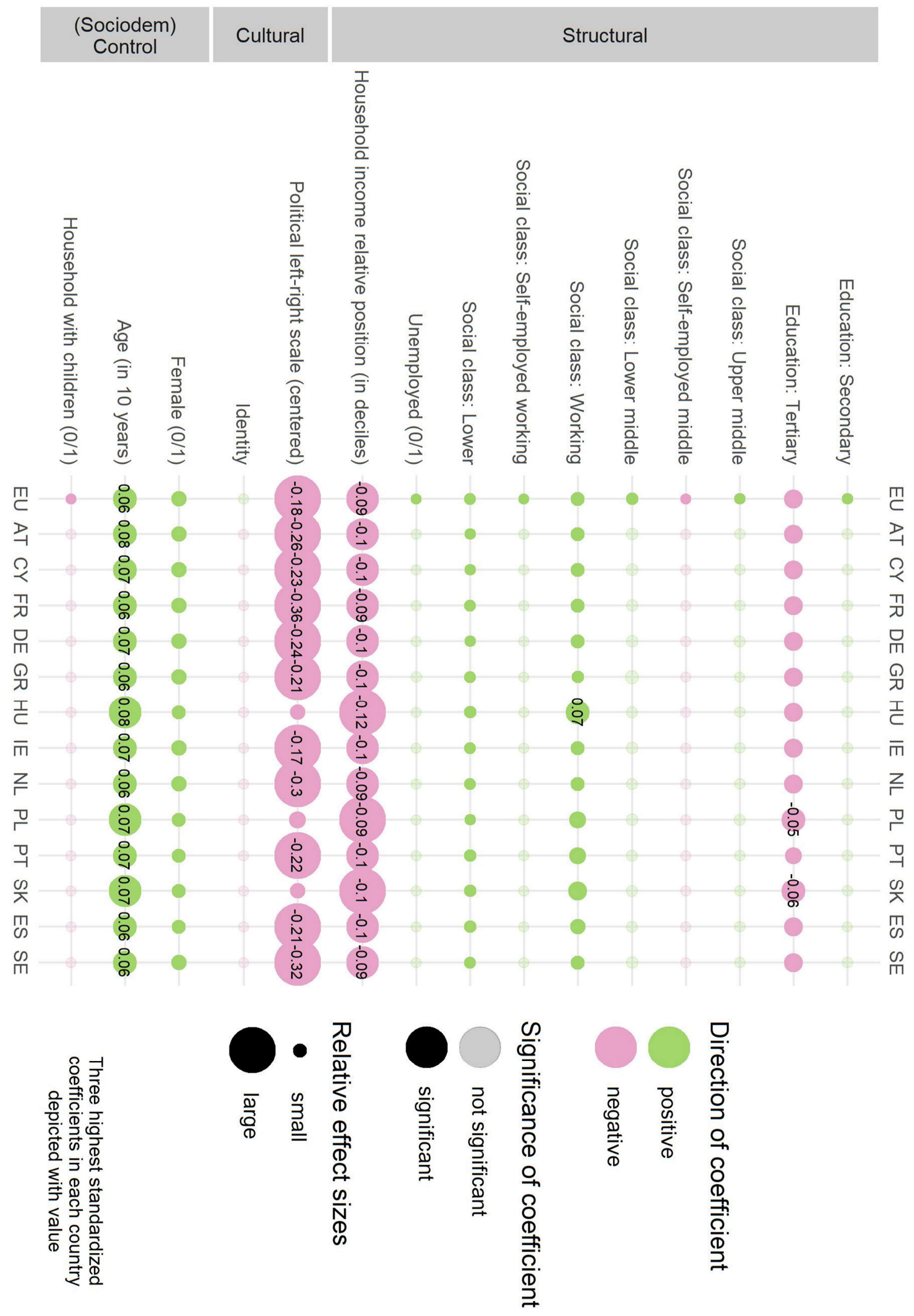

Source: TESS 2016; $N=9048$. 
At first glance, the graph shows that the cleavage structure is by and large uniform across the analytical units when looking at the standardized coefficients. The left-right self-placement is by far the most dominating effect. Exceptions to this rule are Poland, Hungary, and Slovakia, the only post-socialist countries in the sample. Here, income is the strongest predictor. Beyond that, the relative position of the household and the age of the respondent are the two factors that are consistently among the top three strongest effects for each country. That is, the order of the strongest predictors affecting attitudes towards European and national redistribution is comparable: left-right self-placement, relative household income, and age. Noticeable is the lack of prominence of identity. This finding diverges from initial expectations inasmuch as identity does not seem to play a prominent role even for attitudes towards European redistribution. This statement also holds true if all constraints are lifted from the model, so this result is not an artefact of the induced constraints. However, this does match expectations for national redistribution.

Overall, the results show that cleavage structures are similar across nation states and in a European society for attitudes towards redistribution. On the one hand, the structural equation model yielded a well-fitting model for European redistribution when the parameters of national redistribution models were used to constrain the values of the parameter. On the other hand, the patterns, i.e., the direction of effects, are similar. In particular, the relative strength of the effects of European redistribution resembles the relative strength of effects of national redistribution in Ireland most closely.

\section{Discussion and Conclusion}

This paper conducted an empirical thought experiment regarding attitudes towards redistribution applied to 13 European countries. The similarities between attitudes towards European and national redistribution were investigated. The paper formulated two hypotheses: $\mathrm{H} 1$ referred to the expectation that the degree of support for redistribution is comparable at the national and at the European level; $\mathrm{H} 2$ assumed that the mechanisms for the support for redistribution at the national and European level are comparable. The paper then provided indication that these assumptions are empirically well-founded. First, the degree of support for European redistribution among Europeans is on the same level as the support for national redistribution in individual national states. Second, after establishing patterns of cleavage structures related to attitudes towards national redistribution, the paper identified that such a cleavage structure is also apparent at the European level regarding attitudes towards European redistribution. Thus, the paper indicated that social processes at the European and national level have much in common despite vastly different institutional backgrounds in the 13 countries.

An important finding of the paper is related to the nature of the cleavage structure for European redistribution. This sheds light on potential coalitions yet to be formed in the European political arena. First, the most prominent predictor of support for European redistribution was the self-placement on the left-right political value scale, followed by the relative household position of individuals compared to other European households. Second, European identity does not have much explanatory power for the support of European redistribution. 
The paper is not without limitations. For one, the paper could not reliably test whether respondents understood the meaning of European redistribution as does the author of this paper and whether the responses to the issue of European redistribution were informed by genuine understanding of the topic. First, it is questionable whether respondents imagine themselves to be members of a European society when responding to questions about European redistribution. Second, the analysis is not able to rule out spillover mechanisms between attitudes towards national redistribution and attitudes towards European redistribution. Third, the trigger term for respondents in the posed items may well be "redistribution" and not the spatial level at which the redistribution is implemented. While these concerns should be taken up in future studies, the results of this paper should not be discarded due to such concerns. There is extensive evidence that Europeans cognitively think about their social space in European terms (Lahusen and Kiess 2019; Delhey and Kohler 2005), so understanding European redistribution within a European-wide framework is plausible. Taking this into account, it is unlikely that the similarities between the two spatial levels are solely due to spillover effects (Baute et al. 2019). Furthermore, the results also indicate that shifting the spatial space does not matter because the issue at hand (i.e., redistribution) overrides the spatial anchoring.

Another limitation of the paper is that the empirical models employed are not sophisticated. While this is intended, as the analytical set-up is rather bold, much room is left to empirically investigate in more detail the robustness of the effects observed in this paper, e.g., expanding the models by trust for national and European institutions. An important quintessence of the paper is, however, that similarities do exist between the two spatial levels and clear analogies can be identified.

Despite the empirical underpinning of the paper, the arguments presented here should by and large be considered a mere thought experiment. The approach presented in this paper is a very sterile way of examining the relationship between national societies and a European society. The approach essentially levels the two social spaces. The essence of the approach is to search for equivalent mechanisms at both national and European levels. However, for the sake of argument and to keep the analysis as simple as possible, the paper refrains from addressing the issue of how national societies and a European society are related (e.g., embedded, nested, hierarchical, parallel) in more detail. ${ }^{17}$

Nonetheless, the results of the thought experiment carried out in this paper regarding the relevant predictors for European redistribution could have consequences for social policy debates in the future. First, the two most prominent factors represent both structural and cultural cleavages (in terms of values, not identity) and can be seen as candidates that help support a political mobilization for the topic of European solidarity in the European social space. The issue of European redistribution has the potential to become a controversy at the European level between left and right-wing parties but also between those who are affluent and those who are economically less well-off. While these divides do not match classic cleavage structures in welfare states, they do have an important consequence for the European political discussion. Namely, if we view the EU as an elite project as findings show that affluent individuals are more likely to exhibit transnational practices (Delhey et al. 2015; Mau and Mewes 2009) and if at the

\footnotetext{
${ }^{17}$ An example of fusing the mechanisms of the different levels together would be to assess how dispositions related to the national level influence attitudes related to European issues. For an example, see Baute et al. (2019).
} 
same time those from wealthier households support European redistribution to a lesser degree, then who will stand up for European redistribution in European debates?

Furthermore, it is important to note that identity does not play a prominent role for attitudes towards European redistribution. This is in stark contrast to findings of previous scholars. Have others been overestimating the effect of identification? Or does this study underestimate its relevance? One fundamental difference in this study is that national identity was not added to the same model as European identity. Rather, the analysis looked at how the role of identity is relevant for solidarity in general at the two spatial levels. Capturing national identity and European identity at the same time was not part of the research agenda. Thus, we should not rush to conclude that the support of European redistribution is not grounded in a decisive wefeeling as the issue is more complex than that. But just because someone identifies as European does not mean that they will endorse everything that is pro-European. Identifying with Europe may merely suggest that individuals are capable of thinking in transnational terms. Furthermore, that European identity is not significant is in line with findings by Gerhards and colleagues (2019b) who did not find a significant effect of European identity but found that having a national identity discourages support for European redistribution. This final insight suggests that the weak operationalization of identity could potentially also be a culprit for the weak role of European identity for European level attitudes.

Overall, the results contribute to the broader sociological discourse on Europeanization. The results highlight important aspects of European integration. It seems that beyond the increasing political and economic harmonization, European integration is coupled with signs of an emerging European society. And this emerging social entity seems to reflect some features of national societies. To understand European social developments, contrasting national and European processes can bring about important insights.

\section{Acknowledgements}

The paper was developed as part of a project on European solidarity in collaboration with Jürgen Gerhards, Holger Lengfeld, Florian K. Kley and Maximilian Priem. Therefore, it partially integrates the project's analytical strategy as described in the book by Gerhards and colleagues (2019a). I would also like to thank Stefanie Börner for the helpful discussion about the paper. I also appreciate the helpful critiques of the three anonymous reviewers, which provided me with thoughtful feedback and furthered the development of the paper. The paper has furthermore benefited greatly from Monica Budowski's insightful suggestions and attentive editorial remarks.

\section{Declaration of conflicting interests}

The author declared no potential conflicts of interest with respect to the research, authorship, and publication of this article. 


\section{Funding}

The TESS data is a result of a joint venture between two research groups from (1) the international research project Solidarity in Europe: Empowerment, Social Justice and Citizenship SOLIDUS funded by the European Commission as part of the Horizon 2020 research programme (Grant Agreement No. 649489) and (2) the Horizontal Europeanization research unit funded by the German Research Foundation (DFG) (FOR 1539).

\section{References}

Alesina, Alberto, and Paola Giuliano (2011). Preferences for Redistribution. In: Handbook of social economics. Volume $1 A-1 B$. Handbooks in economics, eds. Alberto Bisin, Jess Benhabib and Matthew O. Jackson, 93-131. Amsterdam: Elsevier/North-Holland.

Andersen, Robert, and Josh Curtis (2015). Social Class, Economic Inequality, and the Convergence of Policy Preferences: Evidence from 24 Modern Democracies. Canadian review of sociology $=$ Revue canadienne de sociologie 52, 266-88.

Andersen, Robert, Joshua Curtis and Robert Brym (2021). Public support for social security in 66 countries: Prosperity, inequality, and household income as interactive causes. The British Journal of Sociology.

Andreß, Hans-Jürgen, and Thorsten Heien (2001). Four Worlds of Welfare State Attitudes? A Comparison of Germany, Norway, and the United States. European Sociological Review 17, 337-356.

Armingeon, Klaus, and Giuliano Bonoli (2006). The Politics of Post-Industrial Welfare States. Adapting Post-War Social Policies to New Social Risks, vol. 9. London: Routledge.

Arts, Wil, and John Gelissen (2001). Welfare states, solidarity and justice principles. Does the type really matter? Acta Sociologica 44, 283-299.

Baute, Sharon, and Bart Meuleman (2020). Public attitudes towards a European minimum income benefit. How (perceived) welfare state performance and expectations shape popular support. Journal of European Social Policy 5, 1-17.

Baute, Sharon, Bart Meuleman and Koen Abts (2019). Welfare state attitudes and support for social Europe. Spillover or obstacle? Journal of Social Policy 48, 127-145.

Baute, Sharon, Bart Meuleman, Koen Abts and Marc Swyngedouw (2018). Measuring Attitudes Towards Social Europe: A Multidimensional Approach. Social Indicators Research 137, 353-378.

Bayertz, Kurt (1999). Solidarity, vol. 5. Dordrecht: Springer.

Bechtel, Michael M., Jens Hainmueller and Yotam Margalit (2014). Preferences for International Redistribution: The Divide over the Eurozone Bailouts. American Journal of Political Science 58, 835-856.

Beck, Ulrich, and Edgar Grande (2007). Cosmopolitan Europe. Oxford: Polity Press.

Berg, Linda (2007). Multi-level Europeans. The Influence of Territorial Attachments on Political Trust and Welfare Attitudes. Göteborg: Department of Political Science Statsvetenskapliga institutionen.

Bergh, Andreas (2005). On the Counterfactual Problem of Welfare State Research: How Can We Measure Redistribution? European Sociological Review 21, 345-357. 
Blekesaune, Morten, and Jill Quadagno (2003). Public Attitudes toward Welfare State Policies. A Comparative Analysis of 24 Nations. European Sociological Review 19, 415-427.

Bonoli, Giuliano, and Silja Häusermann (2009). Who wants what from the welfare state? European Societies 11, 211-232.

Börner, Stefanie (2015). From national to European solidarity? The negotiation of redistributive spaces. In: European integration, processes of change and the national experience. Palgrave Studies in European Political Sociology, eds. Stefanie Börner and Monika Eigmüller. Basinstoke: Palgrave Macmillan.

Börner, Stefanie (2020). Marshall revisited: EU social policy from a social-rights perspective. Journal of European Social Policy, 1-15.

Börner, Stefanie, and Monika Eigmüller (2018). Social security in Europe. Towards a diachronic perspective for analysing social policy rescaling. Culture, Practice \& Europeanization 3, 3-18.

Bremer, Björn, Theresa Kuhn, Maurits Meijers and Francesco Nicoli (2021). Viral Solidarity? EU Solidarity and Risk-Sharing in the COVID-19 Crisis.

Brooks, Clem, and Jeff Manz (2006). Why Do Welfare States Persist? The Journal of Politics 68, 816-827.

Brooks, Clem, and Stefan Svallfors (2010). Why does class matter? Policy attitudes, mechanisms, and the case of the Nordic countries. Research in Social Stratification and Mobility 28, 199-213.

Ciornei, Irina, and Ettore Recchi (2017). At the Source of European Solidarity: Assessing the Effects of Cross-border Practices and Political Attitudes. Journal of Common Market Studies 55, 468-485.

Clark, David B. (1973). The Concept of Community: A Re-Examination. The Sociological Review 21, 397-416.

Dallinger, Ursula (2010). Public support for redistribution: what explains cross-national differences? Journal of European Social Policy 20, 333-349.

Delhey, Jan, Emanuel Deutschmann and Katharina Cirlanaru (2015). Between 'class project' and individualization: The stratification of Europeans' transnational activities. International Sociology 30, 269-293.

Delhey, Jan, and Ulrich Kohler (2005). From Nationally Bounded to Pan-European Inequalities? On the Importance of Foreign Countries as Reference Groups. European Sociological Review 22, 125-140.

Deutsch, Karl W (1953). The Growth of Nations: Some Recurrent Patterns of Political and Social Integration. World Politics 5, 168-195.

Deutsch, Karl W. (1960). The Propensity to International Transactions. Political Studies 8, 147-155.

Deutsch, Karl W. (1979). Tides among nations. New York: Free Press.

Deutschmann, Emanuel, Jan Delhey, Monika Verbalyte and Auke Aplowski (2018). The power of contact: Europe as a network of transnational attachment. European Journal of Political Research 57, 963-988.

Díez Medrano, Juan (2010). A New Society in the Making. European Integration and European Social Groups. KFG Working Paper No. 12. Berlin: Kolleg-Forschergruppe (KFG) „The Transformative Power of Europe“, Freie Universität Berlin.

Durkheim, Émile (1933 [1893]). The Division of Labor in Society. New York: Macmillan. 
Esping-Andersen, Gøsta (1990). The Three Worlds of Welfare Capitalism. Princeton, N.J.: Princeton University Press.

ESS Round 4: European Social Survey (2008). 2016. ESS-4 2008 Documentation Report. Edition 5.4. http://www.europeansocialsurvey.org/data/conditions of use.html.

Evans, Geoffrey (1992). Testing the validity of the Goldthorpe class schema. European Sociological Review 8, 211-232.

Favell, Adrian, and Virginie Guiraudon, eds. (2011a). Sociology of the European Union. Basingstoke: Palgrave Macmillan.

Favell, Adrian, and Virginie Guiraudon (2011b). Sociology of the European Union. An Introduction. In Sociology of the European Union, eds. Adrian Favell and Virginie Guiraudon, 1-24. Basingstoke: Palgrave Macmillan.

Ferrera, Maurizio (2014). Social Europe and its Components in the Midst of the Crisis: A Conclusion. West European Politics 37, 825-843.

Ferrera, Maurizio (2017). The European Social Union. A Missing but Necessary 'Political Good'. In A European social union after the crisis, eds. Frank Vandenbroucke, Catherine Barnard and Geert d. Baere, 47-67. Cambridge: Cambridge University Press.

Fligstein, Neil (2010). Euroclash: the EU, European identity, and the future of Europe. Oxford: Oxford University Press.

García-Sánchez, Efraín, Danny Osborne, Guillermo B. Willis and Rosa Rodríguez-Bailón (2020). Attitudes towards redistribution and the interplay between perceptions and beliefs about inequality. The British journal of social psychology 59, 111-136.

Gelissen, John (2000). Popular Support for Insitutionalised Solidarity. A Comparison between European Welfare States. International Journal of Social Welfare 9, 285-300.

Gerhards, Jürgen, Zsófia S. Ignácz, Florian K. Kley, Holger Lengfeld and Maximilian Priem (2019a). How strong is European welfare solidarity? Results from a comparative survey conducted in $13 \mathrm{EU}$ Member States. In Horizontal Europeanisation. The Transnationalisation of Daily Life and Social Fields in Europe. Routledge advances in sociology, ed. Martin Heidenreich, 39-62. London: Routledge.

Gerhards, Jürgen, Holger Lengfeld and Julia Häuberer (2016). Do European Citizens Support the Idea of a European Welfare State? Evidence from a Comparative Survey Conducted in Three EU Member States. International Sociology 31, 677-700.

Gerhards, Jürgen, Holger Lengfeld, Zsófia S. Ignácz, Florian K. Kley and Maximilian Priem (2019b). European Solidarity in Times of Crisis. Insights from a Thirteen-Country Survey. Abingdon, Oxon, New York, NY: Routledge.

Gerhards, Jürgen, Holger Lengfeld, Marta Soler Gallart, Zsófia S. Ignácz, Florian K. Kley, Maximilian Priem and Raúl Ramos. [unpublished]. Transnational European Solidarity Survey [Codebook].

Goedemé, Tim, Lorena Zardo Trindade and Frank Vandenbroucke (2019). A pan-European perspective on low-income dynamics in the EU. In Decent incomes for all. Improving policies in Europe. International Policy Exchange Series, eds. Béa Cantillon, Tim Goedemé and John R. Hills, 56-82. New York: Oxford University Press. 
Grande, Edgar, and Hanspeter Kriesi (2015). The Restructuring of Political Conflict in Europe and the Politicization of European Integration. In European Public Spheres. Politics is Back. Contemporary European politics, ed. Thomas Risse, 190-224. Cambridge: Cambridge University Press.

Grasso, Maria T., and Christian Lahusen (2020). Solidarity in Europe. A comparative account of citizens' attitudes and practices. In Citizens' solidarity in Europe. Civic engagement and public discourse in times of crises, ed. Christian Lahusen, 29-54. Cheltenham: Edward Elgar Publishing.

Gugushvili, Dimitri, and Tijs Laenen (2021). Two decades after Korpi and Palme's "paradox of redistribution": What have we learned so far and where do we take it from here? Journal of International and Comparative Social Policy, 1-16.

Habermas, Jürgen (2011). Zur Verfassung Europas. Ein Essay [On Europe's Constitution - An Essay]. Frankfurt am Main: Suhrkamp.

Heidenreich, Martin (2016). The Europeanization of Income Inequality before and during the Eurozone Crisis: Inter-, Supra-, and Transnational Perspectives. In Exploring Inequality in Europe. Diverging Income and Employment Opportunities in the Crisis, ed. Martin Heidenreich, 22-47. Cheltenham, Northampton, MA: Edward Elgar.

Heidenreich, Martin (2019). The Europeanisation of social fields and the social space. A theoretical framework. In Horizontal Europeanisation. The Transnationalisation of Daily Life and Social Fields in Europe. Routledge advances in sociology, ed. Martin Heidenreich, 9-35. London: Routledge.

Henjak, Andrija (2010). Political Cleavages and Socio-economic Context: How Welfare Regimes and Historical Divisions Shape Political Cleavages. West European Politics 33, 474-504.

Ignácz, Zsófia S. (2019). Contrasting Generalized and Policy Attitudes toward Social Europe. Understanding the Discrepancies. BSSE Working Paper No. 39. Berlin: Freie Universität Berlin.

Ignácz, Zsófia S., and Eleonora Vlach (2021)[forthcoming]. Mapping European societies. Inequalities and socio-structural developments in member states. In Sociology of Europeanization, eds. Sebastian Büttner, Monika Eigmüller and Susann Worschech, xxx. Munich: De Gruyter Oldenbourg.

ISSP Research Group (1999). International Social Survey Programme: Role of Government 3 - ISSP 1996.

Jacques, Olivier, and Alain Noël (2018). The case for welfare state universalism, or the lasting relevance of the paradox of redistribution. Journal of European Social Policy 28, 70-85.

Jæger, Mads M. (2006). Welfare Regimes and Attitudes Towards Redistribution. The Regime Hypothesis Revisited. European Sociological Review 22, 157-170.

Jæger, Mads M. (2009). United But Divided: Welfare Regimes and the Level and Variance in Public Support for Redistribution. European Sociological Review 25, 723-737.

Johnston, Richard, Keith Banting, Will Kymlicka and Stuart Soroka (2010). National Identity and Support for the Welfare State. Canadian Journal of Political Science 43, 349-377.

Korpi, Walter, and Joakim Palme (1998). The Paradox of Redistribution and Strategies of Equality: Welfare State Institutions, Inequality, and Poverty in the Western Countries. American Sociological Review 63,661 .

Kriesi, Hanspeter (1998). The transformation of cleavage politics. The 1997 Stein Rokkan lecture. European Journal of Political Research 33, 165-185. 
Kriesi, Hanspeter, Edgar Grande, Romain Lachet, Martin Dolezal, Simon Bornschier and Thimoteos Frey (2006). Globalization and the transformation of the national political space: Six European countries compared. European Journal of Political Research 45, 921-956.

Kuhn, Theresa (2015). Experiencing European integration. Transnational lives and European identity. 1. ed. Oxford: Oxford Univ. Press.

Kuhn, Theresa, and Aaron Kamm (2019). The national boundaries of solidarity: a survey experiment on solidarity with unemployed people in the European Union. European Political Science Review 11, 179-195.

Kuhn, Theresa, and Francesco Nicoli (2020). Collective Identities and the Integration of Core State Powers: Introduction to the Special Issue. JCMS: Journal of Common Market Studies 58, 3-20.

Kuhn, Theresa, Francesco Nicoli and Frank Vandenbroucke (2020). Preferences for European unemployment insurance. A question of economic ideology or EU support? Journal of European Public Policy 27, 208-226.

Kuhn, Theresa, Hector Solaz and Erika van Elsas (2018). Practising What You Preach: How Cosmopolitanism Promotes Willingness to Redistribute across the European Union. Journal of European Public Policy 25, 1759-1778.

Kuhn, Theresa, and Florian Stoeckel (2014). When European integration becomes costly: the euro crisis and public support for European economic governance. Journal of European Public Policy 21, 624641.

Lahusen, Christian (2020a). Conclusion. The entangled paths towards European solidarity. In Citizens' solidarity in Europe. Civic engagement and public discourse in times of crises, ed. Christian Lahusen, 177-191. Cheltenham: Edward Elgar Publishing.

Lahusen, Christian (2020b). European solidarity. An introduction to a multifaceted phenomenon. In Citizens' solidarity in Europe. Civic engagement and public discourse in times of crises, ed. Christian Lahusen, 1-28. Cheltenham: Edward Elgar Publishing.

Lahusen, Christian, and Johannes Kiess (2019). 'Subjective Europeanization': do inner-European comparisons affect life satisfaction? European Societies 21, 214-236.

Lewin-Epstein, Noah, Amit Kaplan and Asaf Levanon (2003). Distributive Justice and Attitudes Toward the Welfare State. Social Justice Research 16, 1-27.

Lipset, Seymour Martin, and Stein Rokkan (1967). Party Systems and Voter Alignments. Crossnational Perspectives. New York: The Free Press.

Lo, James, Sven-Oliver Proksch and Thomas Gschwend (2014). A Common Left-Right Scale for Voters and Parties in Europe. Political Analysis 22, 205-223.

Mann, Michael (1998). Is there a society called Euro? In Globalization and Europe. Theoretical and empirical investigations, ed. Roland Axtmann, 184-207. London: Pinter.

Marshall, Thomas Humphrey (1964). Class, Citizenship, and Social Development. Essays. 7. ed. Garden City/N.Y: Doubleday.

Mau, Steffen (2005). Democratic Demand for a Social Europe? Preferences of the European Citizenry. International Journal of Social Welfare 14, 76-85. 
Mau, Steffen, and Jan Mewes (2009). Class Divides within Transnationalisation - The German Population and Its Cross-Border Practices. In Mobilities and Inequality, $1^{\text {st }}$ ed., eds. Timo Ohnmacht, Hanja Maksim and Manfred M. Bergman, 165-186. Farnham: Ashgate.

Mau, Steffen, and Jan Mewes (2012). Horizontal Europeanisation in Contextual Perspective. European Societies 14, 7-34.

Meuleman, Bart, Sharon Baute and Koen Abts (2020). Social Europe: A New Integration-Demarcation Conflict? In Shifting solidarities. Trends and developments in European societies, eds. Ine van Hoyweghen, Valeria Pulignano and Gert Meyers, 55-89: Springer International Publishing AG.

Nicoli, Francesco, Theresa Kuhn and Brian Burgoon (2020). Collective Identities, European Solidarity: Identification Patterns and Preferences for European Social Insurance. JCMS: Journal of Common Market Studies 58, 76-95.

Pettersen, Per Arnt (1998). The Welfare State. The Security Dimension. In The Scope of Government. Beliefs in government, v. 3, eds. Ole Borre and Elinor Scarbrough, 198-233. Oxford: Oxford University Press.

Raspotnik, Andreas, Jacob, Marine and Laura Ventura (2012). The issue of solidarity in the European Union. TEPSA Paper.

Roller, Edeltraud (1998). The Welfare State. The Equality Dimension. In The Scope of Government. Beliefs in government, v. 3, eds. Ole Borre and Elinor Scarbrough, 165-197. Oxford: Oxford University Press.

Roosma, Femke, John Gelissen and Wim van Oorschot (2013). The Multidimensionality of Welfare State Attitudes. A European Cross-National Study. Social Indicators Research 113, 235-255.

Schmidt-Catran, Alexander W. (2016). Economic inequality and public demand for redistribution: combining cross-sectional and longitudinal evidence. Socio-Economic Review 14, 119-140.

Spurk, Jan (2014). European construction and sociology. In Routledge Handbook of European Sociology. Routledge International Handbooks, eds. Sokratis Koniordos and Alexandros Kyrtsis, 116-126. London: Routledge.

Svallfors, S. (1997). Worlds of Welfare and Attitudes to Redistribution: A Comparison of Eight Western Nations. European Sociological Review 13, 283-304.

Svallfors, Stefan (2004). Class, Attitudes and the Welfare State: Sweden in Comparative Perspective. Social Policy and Administration 38, 119-138.

Teney, Céline, and Emanuel Deutschmann (2018). Transnational Social Practices: A Quantitative Perspective. In Emerging Trends in the Social and Behavioral Sciences, eds. Robert A. Scott, S.M Kosslyn and Marlis C. B. Buchmann, 1-15. Hoboken, NJ.: John Wiley \& Sons.

Tönnies, Ferdinand (2005[1935]). Gemeinschaft und Gesellschaft. Grundbegriffe der reinen Soziologie. Nachdr. der 8. Aufl. 1935, 4., unveränd. Aufl. Darmstadt: Wiss. Buchges.

van Oorschot, Wim, Wil Arts and Loek Halman (2005). Welfare State Effects on Social Capital and Informal Solidarity in the European Union. Evidence from the 1999/2000 European Value Survey. Policy \& Politics 33, 33-54.

Vandenbroucke, Frank, Brian M. Burgoon, Theresa Kuhn, Francesco Nicoli, Stefano Sacchi, David van der Duin and Sven Hegewald (2018). Risk Sharing When Unemployment Hits. How Policy Design 
Influences Citizen Support For European Unemployment Risk Sharing (EURS). Policy report. AISSR Policy Report No. 1. Amsterdam: Amsterdam Institute for Social Science Research (AISSR).

Vasilopoulou, Sofia, and Liisa Talving (2020). Poor versus rich countries: a gap in public attitudes towards fiscal solidarity in the EU. West European Politics 43, 919-943.

Verhaegen, Soetkin (2018). What to expect from European identity? Explaining support for solidarity in times of crisis. Comparative European Politics 16, 871-904.

Whelan, Christopher T., and Bertrand Maître (2009). The ‘Europeanisation’ of reference groups. European Societies 11, 283-309.

Wright, Matthew, and Tim Reeskens (2013). Of what cloth are the ties that bind? National identity and support for the welfare state across 29 European countries. Journal of European Public Policy 20, 1443-1463.

Zürn, Michael, and Pieter de Wilde (2016). Debating globalization: cosmopolitanism and communitarianism as political ideologies. Journal of Political Ideologies 21, 280-301. 


\section{Appendix}

Table A1: Descriptive statistics

\begin{tabular}{|c|c|c|c|c|}
\hline Variable & Mean/Percentage & SD & Min & Max \\
\hline Support for (national) redistribution & 2.3 & 0.906 & 0 & 3 \\
\hline Support for (European) redistribution & 2.22 & 0.955 & 0 & 3 \\
\hline \multicolumn{5}{|l|}{ Level of education } \\
\hline Primary or less & 3.9 & - & 0 & 1 \\
\hline Secondary & 56.4 & - & 0 & 1 \\
\hline Tertiary & 39.7 & - & 0 & 1 \\
\hline \multicolumn{5}{|l|}{ Social class } \\
\hline Upper (Ref.) & 14 & - & 0 & 1 \\
\hline Upper middle & 16.9 & - & 0 & 1 \\
\hline Self-employed middle & 9.3 & - & 0 & 1 \\
\hline Lower middle & 36.3 & - & 0 & 1 \\
\hline Working & 12.2 & - & 0 & 1 \\
\hline Self-employed working & 4.9 & - & 0 & 1 \\
\hline Lower & 6.5 & - & 0 & 1 \\
\hline Unemployed & 6 & - & 0 & 1 \\
\hline Household income relative to nation (deciles) & 6 & 2.833 & 1 & 10 \\
\hline Household income relative to EU (deciles) & 6 & 2.856 & 1 & 10 \\
\hline Identity: Nation & 95 & - & 0 & 1 \\
\hline Identity: EU & 78.8 & - & 0 & 1 \\
\hline Left-right political self-placement & 0 & 2.507 & -5 & 5 \\
\hline Age (in 10 years) & 6 & 1.598 & 1.8 & 9.7 \\
\hline Household with children & 36.3 & - & 0 & 1 \\
\hline Gender: Female & 53.5 & - & 0 & 1 \\
\hline
\end{tabular}

Source: TESS 2016; $N=9048$. 
Table A2: Overview of global fit measure for multi-group analysis, attitudes towards national redistribution.

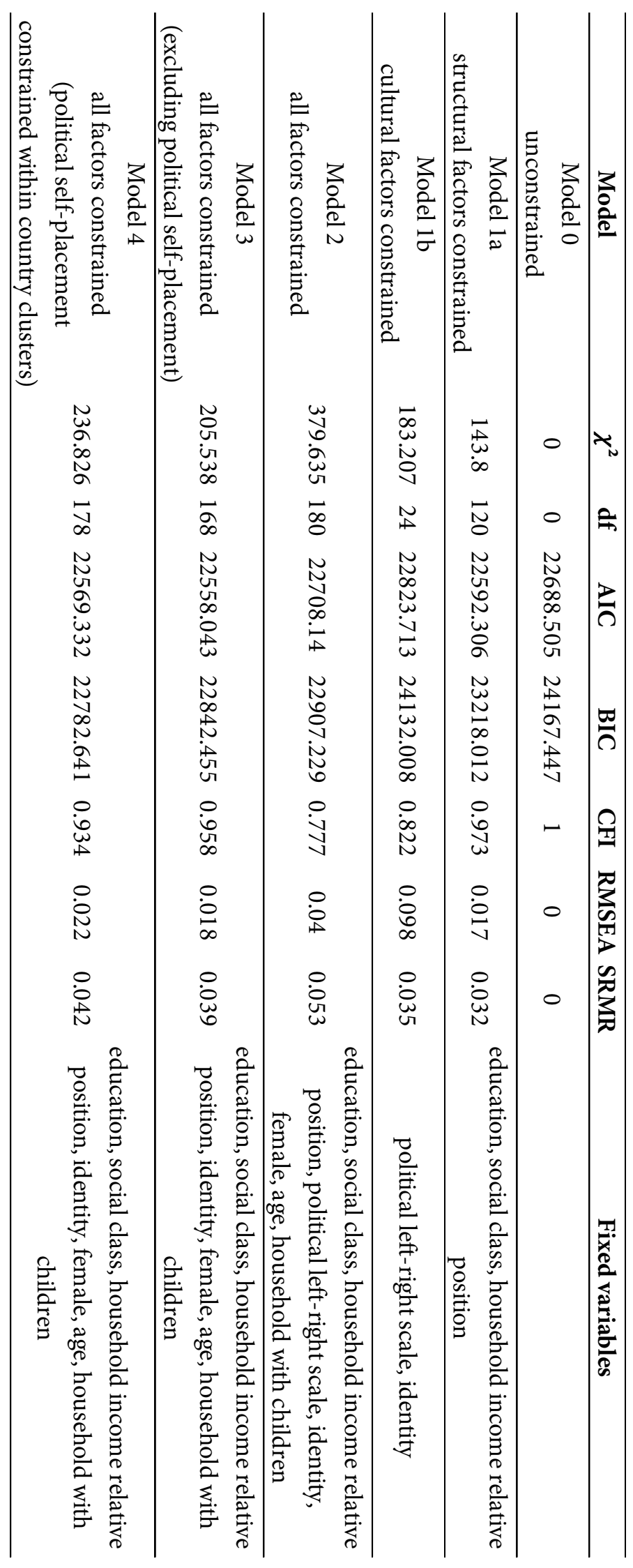

Source: TESS 2016; $N=9048$. 
Figure A1: Overview of standardized coefficients for attitudes towards national and European redistribution.

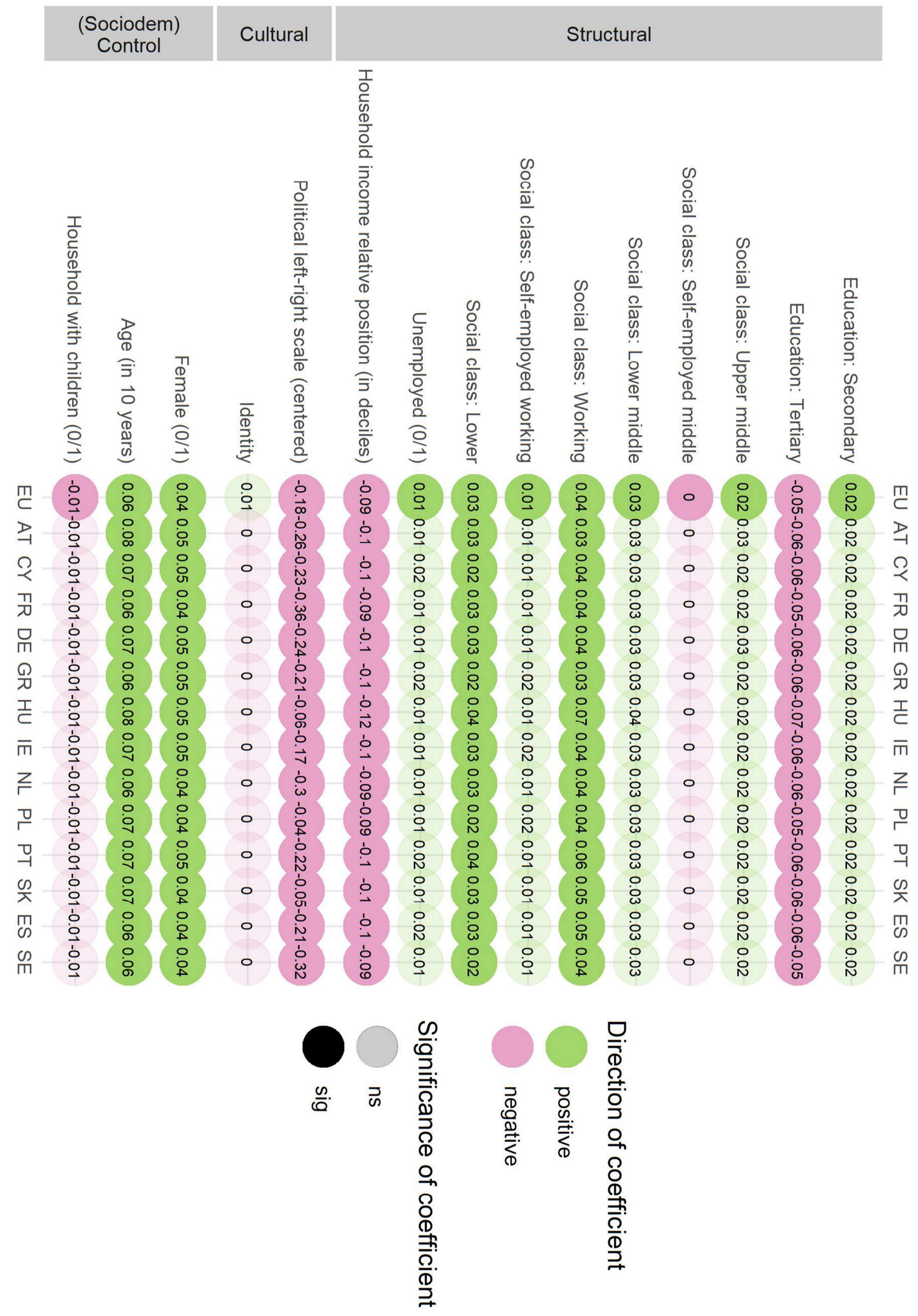

Source: TESS 2016; $N=9048$. 